\title{
VANALI, Ana Crhistina. O Botucudo Tibagyano: análise sobre os registros etnográficos de Telêmaco Borba. Curitiba: SAMP, 2013. 194p.
}

\author{
Adriane dos Santos Tavella Ferrari ${ }^{1}$
}

- Enviado em 27/07/2015

- Aprovado em 05/10/2015

O livro "O Botucudo Tibagyano: análise sobre registros etnográficos de Telêmaco Borba" de autoria de Ana Crhistina Vanali apresenta como objetivo a análise dos registros etnográficos de Telêmaco Borba ${ }^{2}$ e a sua contribuição para os estudos indígenas no cenário paranaense, portanto a obra não é uma biografia de Telêmaco Borba. Está dividida em três capítulos. No primeiro capítulo são retratados diversos momentos e fases de sua vida como sertanista (funcionário do sistema de aldeamentos indígenas no Paraná), político e etnógrafo (escritor de temas indígenas). No segundo capítulo é analisada a publicação "Actualidade Indígena no Paraná" (1908) que é a coletânea dos escritos de Borba primeiramente publicados em jornais e revistas, nacionais e estrangeiras, entre os anos de 1878 e 1907 . No terceiro capítulo, é resgatada a prática do indigenismo no Brasil durante o período de atuação de Borba, fazendo um paralelo com o campo indigenista do Paraná, procurando verificar se neste há uma especificidade traçada pela atuação de Telêmaco Borba.

No primeiro capítulo, a autora, através de uma extensa pesquisa em documentos oficiais (relatórios, ofícios, atas entre outros) traça a trajetória de Telêmaco Borba destacando sua nomeação como funcionário do sistema de aldeamentos, em 1863 até a sua entrada na vida política, em 1880 como presidente da Câmara Municipal de Tibagi. Durante o período de dez anos (1863-1873)

\footnotetext{
${ }^{1}$ Graduada em Ciências Sociais pela Universidade Federal do Paraná. Graduada em Ciências Sociais pela Universidade Federal do Paraná. Especialista em Antropologia Social pela PUC-PR. Endereço eletrônico: adrianeferrari2045@gmail.com.

2 Telêmaco Borba nasceu em 15 de setembro de 1840 em Borda do Campo (atual Piraquara) e faleceu em 23 de dezembro de 1918 em Tibagi vítima de gripe espanhola.
} 
Borba trabalhou como administrador de diversos aldeamentos indígenas e nessa função seguia as políticas indigenistas vigentes, que tinham como propósito a civilização e catequização dos índios para sua integração na sociedade brasileira. Borba não aceitava o processo religioso como processo de integração e defendia a incorporação do índio à sociedade nacional pelo trabalho. Assim, seu papel como sertanista tem grande influência em sua vida política, demonstrado pela autora através dos posicionamentos de Borba como deputado estadual perante as ideias apresentadas na Assembleia Legislativa. A autora conclui esse primeiro capítulo considerando o trabalho de Borba como uma etnografia, apesar de caracterizado pela soma dos fatos observados por ele em diferentes datas e locais e não possuir uma formação especializada. Para uma obra do tipo de "Actualidade Indígena no Paraná” de Telêmaco Borba poder ser utilizada por uma etnografia moderna, ela deve ser localizada no tempo e espaço em que foi concebida. A intenção de Borba era comunicar uma realidade e transmitir suas experiências pessoais acumuladas. Ao mesmo tempo em que era o autor dos seus registros, era personagem de seu tempo. O material registrado indica o que foi observado das situações concretas e não se considera as generalizações feitas pelo observador. A autora finaliza o capítulo propondo uma reavaliação do valor etnográfico de relatos históricos em relação aos dados da observação direta do trabalho de campo, pois o valor depende da investigação para a qual servirá de instrumento.

No segundo capitulo são analisadas as 18 partes do livro de Borba, "Actualidade Indígena no Paraná”, publicado em 1908. Esses registros, segundo Borba, eram uma forma de registrar a contribuição dos indígenas na formação do povo paranaense, pois, esses índios iriam desaparecer, seriam integrados à sociedade nacional. Essas 18 partes são referentes as descrições de lendas, mitos, vocabulário e hábitos da vida cotidiana dos índios paranaenses com que Borba teve contato. Esses relatos etnográficos trazem uma riqueza de detalhes das situações narradas pelos índios. A autora destaca a importância desses registros para os estudos da população indígena do Estado do Paraná, perfazendo uma breve síntese de cada um fazendo referência à data de publicação, de que forma o texto é divido e quais as contribuições de cada texto como dado etnográfico. Finaliza indicando quais os antropólogos que utilizaram os registros de Borba para os estudos contemporâneos das sociedades indígenas paranaenses.

O terceiro e último capítulo "O Indigenismo" traz um panorama da legislação indígena no Brasil e as especificidades da política indigenista do Paraná. A reconstrução do cenário político, referente a práticas indígenas do final do século XIX e início do século XX é de grande relevância para compreender como Telêmaco Borba pensava as questões do seu tempo. A política indigenista 
do Estado tinha como foco principal: a utilização da mão de obra indígena e o processo de “catequizar e civilizar" para a integração do índio na sociedade nacional. Na primeira metade do século XIX surgem os aldeamentos para colocar esses projetos em atividade. No Paraná não foi diferente, o aldeamento com a direção de um frei capuchinho encarregava-se do caráter religioso, os administradores dos aldeamentos (agrupamento de índios alocados) faziam o papel do Estado de “integração". Entre outras práticas, como a sedução (entrega de brindes), sedentarização (fixação de moradia), conversão e trabalho. Borba como administrador de aldeamentos seguiu essas práticas, mas fazia duras críticas ao processo de catequização observando que a conversão religiosa não era função do Estado. Para concluir esse capítulo, a autora destaca a contribuição de outro autodidata para a formação de uma etnologia brasileira - Curt Nimuendajú, que como Borba, tinha uma grande vivência com grupos indígenas. A grande contribuição de Curt Nimuendajú e Telêmaco Borba à etnologia brasileira, é que ambos viveram cotidianamente com os índios, trazendo um olhar de observação direta ao relatarem seus testemunhos, observações e descrições sobre as sociedades indígenas. Esse capítulo é de fundamental importância para a compreensão de políticas indigenistas do Brasil pois a autora faz um percurso histórico das políticas indigenistas do período colonial ao republicano, possibilitando estabelecer uma relação com o contexto em que Telêmaco Borba estava inserido.

As "Considerações Finais" trazem à tona o problema da limitação dos registros etnográficos referente às populações indígenas aldeadas do Paraná. As principais fontes etnográficas sobre os aldeamentos indígenas no Paraná durante o século XX são somente de cinco autores - dois viajantes ingleses: Franz Keller e Thomas Bigg-Wither, dois funcionários do sistema de aldeamentos: Frei Luis Cimitille e Telêmaco Borba e um Presidente da Província do Paraná, Alfredo d'Escragnole Taunay. A autora aponta a limitação dos registros de Borba, pois faltam indicações de uma série de temas e dados que possibilitariam um melhor conhecimento daquelas sociedades indígenas: nada há sobre a constituição ou morfologia dos grupos sociais (o "esqueleto" da vida social, ao qual aludia Bronislaw Malinowski) ou sobre os acontecimentos que marcavam o dia a dia nas aldeias. As referências ao sistema de parentesco são fugazes, como também são praticamente nulas as informações sobre a distribuição espacial dessas populações no aldeamento. Borba contentou-se em descrever aspectos externos e internos das habitações. Pouco nos é dado a conhecer sobre as etapas que acompanham o indígena no seu ciclo de vida (nascimento, nominação, rituais de puberdade, casamentos, rituais funerários), ainda que alguns desses rituais tenham chamado bastante a atenção de Borba. Não há nenhum dado sobre as genealogias, apenas referências rápidas sobre a transmissão hereditária das chefias. Mas enquanto relato de um protagonista que viveu a situação de 
aldeamento, contudo, tais registros ganham outra dimensão, testemunhando um processo interessante a ser observado. Se para a etnologia contemporânea tal obra é lacunar, no entanto traz para a análise informações contextuais valiosas e dados igualmente bem-vindos a respeito dos processos sociais, culturais e políticos das diferentes etnias na situação de aldeamento. 